\title{
Transforming growth factor $\beta 1$ enhances adhesion of endometrial cells to mesothelium by regulating integrin expression
}

\author{
Hee-Jung Choi ${ }^{1,2}$, Mi-Ju Park ${ }^{2}$,Bo-Sung Kim ${ }^{1,2,3}$, Hee-Jin Choi ${ }^{1,2,3}$, Bosun Joo ${ }^{2}$, Kyu Sup Lee ${ }^{4}$,Jung-Hye Choi ${ }^{5}$, \\ Tae-Wook Chung ${ }^{1,2, *}$ E Ki-Tae Ha, ${ }^{1,2,3}$ \\ ${ }^{1}$ Department of Korean Medical Science, School of Korean Medicine, ${ }^{2}$ Healthy Aging Korean Medical Research Center and ${ }^{3}$ Graduate \\ Training Program of Korean Medicine for Healthy-aging, Pusan National University, Yangsan 50612, ${ }^{4}$ Department of Obstetrics \& \\ Gynecology, Pusan National University Hospital, Busan $49241,{ }^{5}$ Department of Life and Nanopharmaceutical Sciences and Department of \\ Oriental Pharmacy, Kyung Hee University, Seoul 02447, Korea
}

Endometriosis is the abnormal growth of endometrial cells outside the uterus, causing pelvic pain and infertility. Furthermore, adhesion of endometrial tissue fragments to pelvic mesothelium is required for the initial step of endometriosis formation outside uterus. TGF- $\beta 1$ and adhesion molecules importantly function for adhesion of endometrial tissue fragments to mesothelium outside uterus. However, the function of TGF- $\beta 1$ on the regulation of adhesion molecule expression for adhesion of endometrial tissue fragments to mesothelium has not been fully elucidated. Interestingly, transforming growth factor $\beta 1$ (TGF- $\beta 1$ ) expression was higher in endometriotic epithelial cells than in normal endometrial cells. The adhesion efficiency of endometriotic epithelial cells to mesothelial cells was also higher than that of normal endometrial cells. Moreover, TGF- $\beta 1$ directly induced the adhesion of endometrial cells to mesothelial cells through the regulation of integrin of $\alpha \mathrm{V}, \alpha 6, \beta 1$, and $\beta 4$ via the activation of the TGF- $\beta 1 /$ TGF- $\beta R I / S m a d 2$ signaling pathway. Conversely, the adhesion of TGF- $\beta 1$-stimulated endometrial cells to mesothelial cells was clearly reduced following treatment with neutralizing antibodies against specific TGF- $\beta 1$-mediated integrins $\alpha \mathrm{V}, \beta 1$, and $\beta 4$ on the endometrial cell membrane. Taken together, these results suggest that TGF- $\beta 1$ may act to promote the initiation of endometriosis by enhancing integrin-mediated cell-cell adhesion. [BMB Reports 2017; 50(8): 429-434]

*Corresponding authors. Ki-Tae Ha, Tel: +82-51-510-8464; Fax: +82-51-510-8420; E-mail: hagis@pusan.ac.kr; Tae-Wook Chung, Tel: +82-51-510-8434; Fax: +82-51-510-8420; E-mail: twchung@ pusan.ac.kr

https://doi.org/10.5483/BMBRep.2017.50.8.097

Received 11 June 2017, Revised 13 July 2017, Accepted 31 July 2017

Keywords: Endometrial cells, Endometriosis, Integrin, Mesothelial cells, TGF- $\beta 1$

\section{INTRODUCTION}

Endometriosis is a common gynecological disorder defined as growth of endometrial tissues outside the uterus. Possible causes include retrograde menstruation, immunological disorders, invasive implantation, and ectopic growth of endometrial tissues $(1,2)$. However, the precise mechanisms that underlie the initial development and subsequent progression of endometriosis are not clear. At the initial stages of the disease, the attachment of retrograde endometrial tissues onto the pelvic mesothelium is a critical step. Several adhesion molecules, including integrin $\alpha v \beta 3, \alpha 4 \beta 1, \operatorname{VCAM}-1$, and Nectin-4, have been suggested to be key factors in regulating the attachment of endometrial and mesothelial tissues (3-6). Furthermore, while previous studies have demonstrated that these adhesion molecules are regulated by cytokines and growth factors (7-12), the mechanisms that underlie this regulation are still not clear.

Transforming growth factor- $\beta$ (TGF- $\beta$ ) is a $25 \mathrm{kDa}$ peptide that plays key roles in the progression of endometriosis (13). TGF- $\beta$ expression is higher in the serum, peritoneal fluid, and cyst tissues of patients with endometriosis than in women without endometriosis (14-16). Among the three subtypes of TGF- $\beta \mathrm{s}$, TGF- $\beta 1$ is generally considered to be a key player in the pathogenesis of endometriosis, due to its pattern of expression and correlation with disease progression $(13,17)$. TGF- $\beta 1$ is involved in the suppression of immune surveillance, cell adhesion and invasion into the peritoneum, and in the growth of implants (13). Peritoneal adhesion of endometrial cells, in particular, is elevated in the presence of TGF- $\beta 1$ (18, 19). The expression of several integrins in different cells is controlled by TGF- $\beta 1$ (20-23); therefore it was suggested that cell-cell interactions that are activated by TGF- $\beta 1$ could be mediated by integrins (13). To date, there have been no reports describing direct evidence for TGF- $\beta 1$-mediated regulation of integrins and other adhesion molecules in endometrial cells, or its role in peritoneal adhesion of

ISSN: 1976-670X (electronic edition)

Copyright (c) 2017 by the The Korean Society for Biochemistry and Molecular Biology

(c) This is an open-access article distributed under the terms of the Creative Commons Attribution Non-Commercial License (http://creativecommons.org/licenses/by-nc/4.0) which permits unrestricted non-commercial use, distribution, and reproduction in any medium, provided the original work is properly cited. 
retrograde endometrium.

In the present study, we demonstrated that autocrine secretion of TGF- $\beta 1$ increased adhesion between endometrial and mesothelial cells through expression of integrin $\alpha \mathrm{V}, \alpha 6$, $\beta 1$, and $\beta 4$. Moreover, blocking these integrins with neutralizing antibodies suppressed the mesothelial adhesion of endometrial cells. Thus, we suggest that TGF- $\beta 1$ may act to promote the initiation of endometriosis by enhancing integrin-mediated cell-cell adhesion.

\section{RESULTS}

TGF- $\beta 1$ expression is increased in endometriotic epithelial cells and is associated with the adhesion of endometrial cells to mesothelial cells

It has been reported that TGF- $\beta 1$ expression is increased in the peritoneal fluid of women with endometriosis $(13,24)$. In the current study, we compared levels of TGF- $\beta 1$ expression in normal human endometrial cells (HES cells) and human endometriotic epithelial cells from endometrial lesions (12Z cells). As shown in Fig. 1A, TGF- $\beta 1$ expression was significantly higher in $12 Z$ cells than in HES cells. Results from several recent studies have suggested that proliferative, secretory, and menstrual endometrial fragments rapidly attach to the peritoneal mesothelium in case of endometriosis (25-28). Therefore, we also investigated differences in the adhesion of HES and $12 Z$ cells to human mesothelial cells (Met-5A). As shown in Fig. 1B, the adhesion ratio of $12 \mathrm{Z}$ cells to Met-5A cells was approximately 3 times higher than that of HES cells. Because TGF- $\beta 1$ expression and adhesion were higher in endometriotic epithelial cells than in normal endometrial cells, we examined whether TGF- $\beta 1$-mediated signaling is involved in the adhesion of $12 \mathrm{Z}$ cells to Met-5A cells.

Interestingly, adhesion rate of TGF- $\beta$ receptor I (TGF- $\beta$ RI) inhibitor (SB-525334, Sigma, St. Louis, MO, USA)-treated $12 \mathrm{Z}$ cells to Met-5A cells was lower than that of $12 \mathrm{Z}$ cells (Fig. 1C). These results suggest that enhanced expression of TGF- $\beta 1$ in $12 Z$ cells affects the adhesion of endometrial cells to mesothelial cells, thus playing a role in the progression of endometriosis.

\section{TGF- $\beta 1$ induces the adhesion of endometrial cells to mesothelial cells through the TGF- $\beta$ RI/Smad2 signaling pathway}

Secretion of TGF- $\beta$ into the peritoneal fluid plays an important role in the establishment of endometriosis $(13,24)$. Thus, we investigated whether TGF- $\beta 1$ played a role in the initial stages of endometriosis formation outside the uterus via direct induction of the adhesion of endometrial cells to mesothelial cells. Adhesion rates of TGF- $\beta 1$-stimulated HES and $12 Z$ cells to Met-5A cells were clearly higher than that of untreated HES and $12 \mathrm{Z}$ cells (Fig. 2A). Furthermore, TGF- $\beta 1$ significantly induced the adhesion of normal endometrial cells to mesothelial
A)
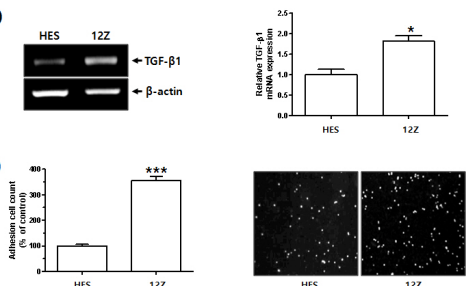

C)

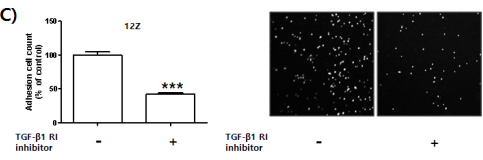

Fig. 1. Enhanced TGF- $\beta 1$ expression in human endometriotic epithelial cells and its function in adhesion of endometrial cells to mesothelial cells. Total RNA was extracted from HES cells and $12 Z$ cells. (A) Levels of TGF- $\beta 1$ mRNA expression were examined using RT-PCR. $\beta$-actin was used as an internal control. Band intensity of TGF- $\beta 1$ mRNA expression was quantified and normalized to $\beta$-actin internal control using densitometry (Image software, NIH). Data obtained from densitometric analyses are shown as bar graph. Data are expressed as fold of control and shown as mean \pm SD for three independent experiments $\left({ }^{*} \mathrm{P}<0.05\right.$ in comparison between two groups). Differences between mean values and two groups were evaluated using Student's t-test and analysis of variance with an unpaired t-test. (B) HES cells $(5 \times$ $10^{5}$ cells) were seeded onto 6-well plate and cultured for $24 \mathrm{~h}$. $12 Z$ cells $\left(3 \times 10^{5}\right.$ cells $)$ were seeded onto $100 \pi$ culture dish plate and cultured for $24 \mathrm{~h}$. HES and $12 \mathrm{Z}$ cells were labeled with CMFDA for $15 \mathrm{~min}$ at $37^{\circ} \mathrm{C}$, then washed in $1 \times \mathrm{PBS}$ and gently transferred onto a Met-5A cell monolayer. Number of HES and $12 \mathrm{Z}$ cells bound to confluent Met-5A cells was manually counted. Four pictures were taken per well and the number of adherent cells was calculated as a percentage of the control cell values and expressed as mean \pm SD for three independent experiments ( $* * * P<0.01$ in comparison between two groups). Differences between mean values and two groups were evaluated using Student's t-test and analysis of variance with an unpaired t-test. (C) $12 \mathrm{Z}$ cells $\left(3 \times 10^{5}\right.$ cells $)$ were seeded onto $100 \pi$ culture dish plate and cultured for $24 \mathrm{~h}$. Medium was replaced and cells were incubated in serum free-medium with or without TGF- $\beta$ RI inhibitor for $24 \mathrm{~h}$. Cells were then labeled with CMFDA for $15 \mathrm{~min}$ at $37^{\circ} \mathrm{C}$, then washed in $1 \times$ PBS and gently transferred onto a Met-5A cell monolayer. Number of cells bound to confluent Met-5A cells was manually counted. Four pictures were taken per well and the number of adherent cells was calculated as a percentage of the control cell values and expressed as mean $\pm \mathrm{SD}$ for three independent experiments $(* * * \mathrm{P}<0.01$ in comparison between two groups). Differences between mean values and two groups were evaluated using Student's t-test and analysis of variance with an unpaired t-test.

cells through activation of Smad-2 signaling. However, treatment with a TGF- $\beta$ RI inhibitor markedly suppressed the TGF- $\beta 1$-induced adhesion of HES cells to Met-5A cells by inhibition of the TGF- $\beta$ RI/Smad2 signaling pathway (Fig. $2 \mathrm{~B}$ and C).

TGF- $\beta 1$ induces the expressions of cell adhesion molecules in endometrial cells

Adhesion molecules, including integrins, CD44, ICAM-1, 


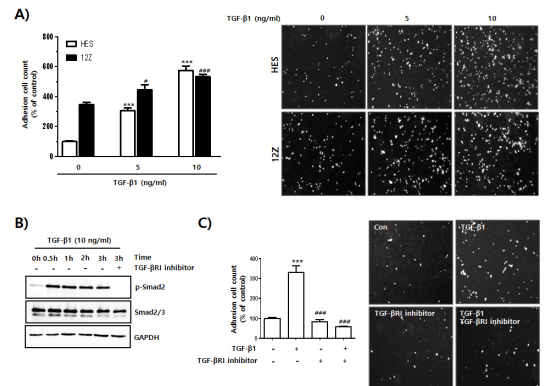

Fig. 2. Increased adhesion of endometrial cells to mesothelial cells by activation of TGF- $\beta 1$-mediated signaling. (A) HES and $12 Z$ cells were seeded and cultured for $24 \mathrm{~h}$. Medium was replaced and cells were incubated in serum free-medium with or without TGF- $\beta 1$ for $24 \mathrm{~h}$. Cells were labeled with CMFDA for 15 $\min$ at $37^{\circ} \mathrm{C}$, then washed in $1 \times \mathrm{PBS}$ and gently transferred onto a Met-5A cell monolayer. After gentle shaking at $20 \mathrm{rpm}$ for 20 min at $37^{\circ} \mathrm{C}$, Cells were washed three times with $1 \times$ PBS to remove unbound cells. Attached cells were visualized using a fluorescent microscope, and quantified using Imagej software. The number of cells in 4 randomly chosen areas in each well was used for statistical analysis. The results from 3 independent experiments were calculated as a percentage of the control cell values and presented as mean $+\mathrm{SD}$. ${ }^{* * * P}<0.001$ compared to control white bar graph ( $1^{\text {st }}$ column). ${ }^{\#} \mathrm{P}<0.05$ and ${ }^{\# \#} \mathrm{P}<$ 0.001 compared to control black bar graph ( $1^{\text {st }}$ column). Differences between mean values of experimental groups were determined using one-way analysis of variance (one-way ANOVA) with a Tukey's post-hoc test, using GraphPad Prism software. (B) HES cells were seeded and cultured for $24 \mathrm{~h}$. Medium was replaced and cells were incubated in serum free-medium with or without TGF- $\beta 1$ in the presence or absence of TGF- $\beta R$ I inhibitor for the indicated times. Phosphorylation levels of Smad2 were analyzed using western blot. GAPDH expression was used as an internal control. (C) HES cells were seeded and cultured for $24 \mathrm{~h}$. Medium was replaced and cells were incubated in serum free-medium with or without TGF- $\beta 1$ in the presence or absence of TGF- $\beta$ RI inhibitor for the indicated times. Cells were labeled with CMFDA for $15 \mathrm{~min}$ at $37^{\circ} \mathrm{C}$, then washed in $1 \times$ PBS and then gently transferred onto a Met-5A cell monolayer. Number of cells bound to confluent Met-5A cells was manually counted. Four pictures were taken per well and the number of adherent cells was calculated as a percentage of the control cell values and shown as mean $\pm \mathrm{SD}$ for three independent experiments. $* * * \mathrm{P}<$ 0.001 compared to negative control $\left(1^{\text {st }}\right.$ column). ${ }^{\# \# \#} P<0.001$ compared to positive control $\left(2^{\text {nd }}\right.$ column). Differences between mean values of experimental groups were determined using one-way ANOVA with a Tukey's post-hoc test, using GraphPad Prism software.

L-selectin and E-cadherin (29) and TGF- $\beta 1$, play pivotal roles in the attachment of endometrial cells outside the uterus i.e., the initiation of endometriosis; however, to the best of our knowledge, there is no direct evidence for a regulatory function of TGF- $\beta 1$ on expressions of adhesion molecules. As shown in Fig. 3A, TGF- $\beta 1$ induced the expression of integrins $\alpha \mathrm{V}, \alpha 6, \beta 1$, and $\beta 4$. The expression levels of integrin $\beta 5$, CD44s, ICAM-1, and L-selectin were not increased by TGF- $\beta 1$ treatment, and integrin $\beta 3$ and E-cadherin were not detectable under the same conditions. To further investigate this result,
A)

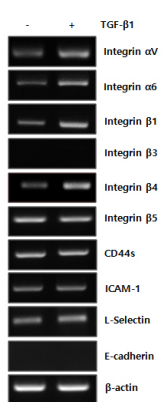

B)

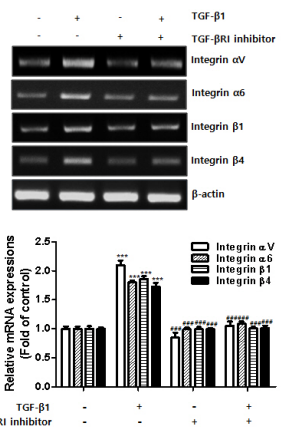

Fig. 3. Expressions of integrin $\alpha \mathrm{V}, \alpha 6, \beta 1$, and $\beta 4$ induced by TGF- $\beta 1$ in endometrial cells. HES cells were seeded and cultured for $24 \mathrm{~h}$. Medium was replaced and cells were incubated in serum free-medium with or without TGF- $\beta 1$ for 24 h. Total RNA was extracted from the cells. (A) mRNA expression of adhesion molecules was examined using RT-PCR. $\beta$-actin was used as an internal control. (B) HES cells were seeded and cultured for $24 \mathrm{~h}$. Medium was replaced and the cells were incubated in serum free-medium with or without TGF- $\beta 1$ in the presence or absence of TGF- $\beta$ RI inhibitor for $24 \mathrm{~h}$. Total RNA was extracted from the cells. Expression levels of integrin $\alpha \mathrm{V}, \alpha 6, \beta 1$, and $\beta 4$ were examined using RT-PCR. $\beta$-actin was used as an internal control. Band intensity of each integrin mRNA expression was quantified and normalized to $\beta$-actin internal control using densitometry. Data obtained from densitometric analyses are shown as bar graph. Data are expressed as fold of control and are shown as mean \pm SD for three independent experiments $* * * P<0.001$ compared to each negative control ( $1^{\text {st }}$ column). ${ }^{\# \# \# ~} \mathrm{P}<0.001$ compared to each positive control ( $2^{\text {nd }}$ column). Differences between mean values of experimental groups were determined using a one-way ANOVA with a Tukey's post-hoc test, using GraphPad Prism software.

we used a TGF- $\beta$ RI inhibitor and measured levels of integrin $\alpha \mathrm{V}, \alpha 6, \beta 1$, and $\beta 4 \mathrm{mRNA}$ expression. Treatment with the TGF- $\beta R$ I inhibitor clearly reduced integrin expression levels $(\alpha \mathrm{V}, \alpha 6, \beta 1$, and $\beta 4)$ in HES cells induced by TGF- $\beta 1$ (Fig. 3B). Thus, our data showed that TGF- $\beta 1$ induced adhesion of endometrial cells to mesothelial cells by enhancing the expression of integrins $\alpha \mathrm{V}, \alpha 6, \beta 1$, and $\beta 4$.

\section{Neutralizing integrin $\alpha \mathrm{V}, \beta 1$, and $\beta 4$ inhibits adhesion of TGF- $\beta 1$-stimulated HES cells to Met-5A cells}

We then started to investigate whether integrin subunits $\alpha \mathrm{V}$, $\beta 1$, and $\beta 4$ regulated the adhesion of endometrial cells to mesothelial cells through TGF- $\beta 1$-induced expression of integrin heterodimers $\alpha \mathrm{V} \beta 1, \alpha 6 \beta 1$, and $\alpha 6 \beta 4$ in endometrial cells. We assessed the adhesion of TGF- $\beta 1$-stimulated endometrial cells to mesothelial cells in the presence of neutralizing antibodies against integrin subunits $\alpha \mathrm{V}, \beta 1$, and $\beta 4$. As shown in Fig. 4, TGF- $\beta 1$ greatly enhanced the adhesion of endometrial cells to mesothelial cells. However, this adhesion was significantly reduced when the TGF- $\beta 1$-mediated expression levels of integrin dimers $\alpha \mathrm{V} \beta 1, \alpha 6 \beta 1$, and $\alpha 6 \beta 4$ on endometrial cell surfaces were disrupted by neutralizing antibodies (Fig. 4). These results suggested that secreted TGF- $\beta 1$ may play a role 


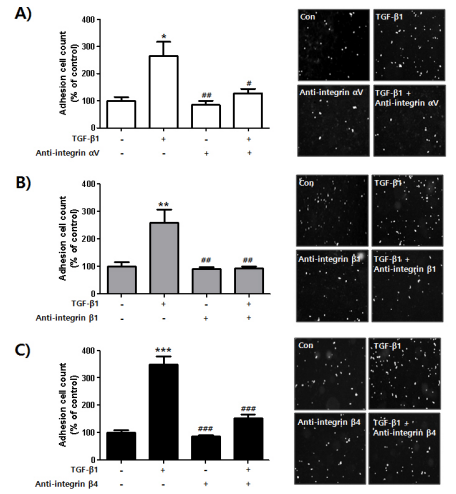

Fig. 4. Blocking adhesion of TGF- $\beta 1$-stimulated endometrial cells to mesothelial cells using integrin $\alpha \mathrm{V}, \beta 1$, and $\beta 4$ neutralizing antibodies. HES cells were seeded and cultured for $24 \mathrm{~h}$. Medium was replaced and cells were incubated in serum free-medium with or without TGF- $\beta 1$ in the presence or absence of integrin (A) $\alpha \mathrm{V}$, (B) $\beta 1$, or (C) $\beta 4$ antibodies for $24 \mathrm{~h}$. Cells were labeled with CMFDA for $15 \mathrm{~min}$ at $37^{\circ} \mathrm{C}$, then washed in 1 $\times$ PBS and gently transferred onto a Met-5A cell monolayer. Number of cells bound to confluent Met-5A cells was manually counted. Four pictures were taken per well and the number of adherent cells was calculated as a percentage of the control cell values and shown as mean \pm SD for three independent experiments. ${ }^{*} \mathrm{P}<0.05,{ }^{* * \mathrm{P}}<0.01,{ }^{* * * \mathrm{P}}<0.001$ compared to each negative control ( $1^{\text {st }}$ column of each graph). " $\mathrm{P}<0.05$, $\# P<0.01, \# \# P=0.001$ compared to each positive control $\left(2^{\text {nd }}\right.$ column of each graph). Differences between mean values of experimental groups were determined using a one-way ANOVA with a Tukey's post-hoc test, using GraphPad Prism software.

in the adhesion of endometrial fragments generated by menstruation and the passage of these fragments outside the uterus, where endometriosis is initiated through attachment to the mesothelium. The molecular mechanism involves enhanced expression of integrin heterodimers $\alpha \mathrm{V} \beta 1$, $\alpha 6 \beta 1$, and $\alpha 6 \beta 4$ in endometrial cells.

\section{DISCUSSION}

Integrins are heterodimeric membrane proteins composed of non-covalently associated $\alpha$ and $\beta$ subunits, that are essential for linking the extracellular matrix to the cytoskeleton. In mammals, there are $18 \alpha$ subunits and $8 \beta$ subunits that can assemble into 24 different $\alpha \beta$ combinations (30). The role of integrins in the reproductive system has been studied for over 20 years. A major focus of these studies has been the involvement of these transmembrane receptors in embryoendometrial interactions during the implantation window (31). Many researchers have continued to work towards elucidating the function of integrins during endometriosis (32) and have identified potential biomarkers for use in diagnosis and treatment of the disease (33).

Several integrins, including $\alpha v \beta 3, \alpha v \beta 5, \alpha v \beta 6, \alpha 4 \beta 1$, and $\alpha 6 \beta 1$, have been reported to mediate the attachment of endometrial cells to the mesothelium $(4,34-36)$. The expression of these integrins is tightly regulated by diverse molecules, such as interleukin (IL)-1, IL-8, macrophage inhibitory factor (MiR)-183, prostaglandin E2, and a cannabinoid receptor agonist $(7,9-11,37,38)$. However, despite the obvious importance of TGF- $\beta 1$ in the progression of endometriosis $(13,17)$, there have been no reports of the TGF- $\beta 1$ function in the regulation of integrins in endometrial cells. Thus, we examined the regulation of integrins by TGF- $\beta 1$ and their role in the initiation of endometriosis.

First, we confirmed the correlation between endometrialmesothelial adhesion and TGF- $\beta$ expression. Our results clearly showed that autocrine expression of TGF- $\beta 1$ in endometrial cells positively regulated their attachment to mesothelial cells. In human endometriosis lesions, TGF- $\beta 1$ expression has been found in macrophages, endometrial epithelial cells, endometrial stromal cells, and mesothelial cells $(13,24)$. Elevated levels of secreted TGF- $\beta 1$ in peritoneal fluid influenced many steps in the progression of endometriosis, including immune surveillance, cell adhesion and invasion into the peritoneum, angiogenesis, and growth of implants (13, 17). The response of TGF- $\beta 1$ measured by endometrialmesothelial adhesion is different between normal endometrial HES cells and ectopic endometrial cells (12Z). Rai et al. (39) reported that expression of adhesion molecules is different between the normal endometrium and endometriosis tissues. Thus, we proposed that it might be caused by elevated expression of TGF- $\beta 1$ in $12 Z$ cells. We further showed that the use of a specific TGF- $\beta$ RI inhibitor to inhibit the activity of TGF- $\beta 1$ activity greatly reduced mesothelial adhesion of TGF- $\beta 1$-stimulated HES cells. From these results, we postulated that secreted TGF- $\beta 1$ may act in an autocrine fashion on endometrial-mesothelial interactions.

To identify the factors that mediate TGF- $\beta 1$-enhanced cell-cell interactions, we analyzed the expression of several adhesion molecules that are known to be important in the development of endometriosis $(40,41)$. Levels of integrins $\alpha \mathrm{v}$, $\alpha 6, \beta 1$ and $\beta 4$ mRNA were clearly increased following TGF- $\beta 1$ treatment. The expression levels of integrin $\beta 5$, CD44s, ICAM-1, L-selectin were not increased, and integrin $\beta 3$ and E-cadherin were not detectable under the same conditions. We further suppressed the activity of activity of TGF- $\beta 1$ by examining whether the expression levels of integrins $\alpha \mathrm{V}, \alpha 6$, $\beta 1$, and $\beta 4$ were dependent on TGF- $\beta 1$.

Previous studies reported that several integrins, such as $\alpha \mathrm{V}$, $\beta 1$, and $\beta 3$, were positively regulated by TGF- $\beta 1$ in fibroblast, glioblastoma, and kidney epithelial cells $(23,42,43)$. In the present study, expression levels of integrins $\alpha \mathrm{V}, \alpha 6$, and $\beta 1$ were increased in normal endometrial HES cells following TGF- $\beta 1$ treatment, but integrin $\beta 3$ expression was not affected by the same conditions. In A549 lung cancer cells, sustained ERK activity induced by TGF- $\beta 1$ is involved in the induction of integrin $\beta 3$ (44). In the current study, phosphorylation of Smad2 was found to be a major step in the signaling pathway 
involved in TGF- $\beta 1$-stimulated integrin expression and endometrial-mesothelial adhesion. Previous studies demonstrated that integrin $\beta 4$ is negatively regulated by TGF- $\beta 1$ in fibroblast and mammary gland cells via epigenetic modifications $(45$, 46). By contrast, we found that TGF- $\beta 1$ increased the expression of integrin $\beta 4$ in endometrial cells. Although the precise molecular machinery involved in the modulation of integrin $\beta 4$ by TGF- $\beta 1$ is not fully elucidated, we hypothesize that the differential expression of integrin $\beta 4$ is mainly due to tissue specificity.

Next, we confirmed the role of induced integrins on endometrial-mesothelial attachment by neutralizing the action of integrins in endometrial cells. Addition of antibodies against integrins $\alpha \mathrm{V}, \beta 1$, and $\beta 4$ significantly blocked the adhesion of endometrial cells onto mesothelium. To the best our knowledge, this is the first report to show that blocking the functions of integrins $\alpha \mathrm{V}, \beta 1$, and $\beta 4$ with neutralizing antibodies reduced the development of endometriosis by inhibiting endometrialmesothelial adhesion.

In conclusion, as illustrated in supplementary Fig. 1, we demonstrated that TGF- $\beta 1$ increased endometrial-mesothelial adhesion via autocrine regulation. This TGF- $\beta 1$-stimulated adhesion is mediated by integrins $\alpha \mathrm{V}, \alpha 6, \beta 1$, and $\beta 4$, and blocking these integrins with neutralizing antibodies reduced the mesothelial adhesion of endometrial cells. We therefore propose that TGF- $\beta 1$-stimulation of integrins $\alpha \mathrm{V}, \alpha 6, \beta 1$, and $\beta 4$ could be a good target for the development of new methods aimed at preventing or treating endometriosis.

\section{MATERIALS AND METHODS}

See supplementary information.

\section{ACKNOWLEDGEMENTS}

This study was supported by a grant from the National Research Foundation of Korea (NRF) funded by the Ministry of Science, ICT \& Future Planning (MISP), of the Korean Government (Grant no. NRF-2015R1D1A1A01060264 to K.T.H), and a grant of the Traditional Korean Medicine R\&D Project, Ministry for Health \& Welfare, Republic of Korea (Grant no. HI15C0188 to T.W.C).

\section{CONFLICTS OF INTEREST}

The authors have no conflicting financial interests.

\section{REFERENCES}

1. Ping S, Ma C, Liu P et al (2016) Molecular mechanisms underlying endometriosis pathogenesis revealed by bioinformatics analysis of microarray data. Arch Gynecol Obstet 293, 797-804

2. Nothnick W and Alali Z (2016) Recent advances in the understanding of endometriosis: the role of inflammatory mediators in disease pathogenesis and treatment. F1000Res 5

3. Bedir R, Sehitoglu I, Balik G et al (2016) The role of the adhesion molecule Nectin-4 in the pathogenesis of endometriosis. Clin Exp Obstet Gynecol 43, 463-466

4. Schutt AK, Atkins KA, Slack-Davis JK and Stovall DW (2015) VCAM-1 on peritoneum and alpha4beta1 integrin in endometrium and their implications in endometriosis. Int J Gynecol Pathol 34, 85-89

5. Sundqvist J, Andersson KL, Scarselli G, Gemzell-Danielsson K and Lalitkumar PG (2012) Expression of adhesion, attachment and invasion markers in eutopic and ectopic endometrium: a link to the aetiology of endometriosis. Hum Reprod 27, 2737-2746

6. Surrey ES, Minjarez DA and Schoolcraft WB (2007) The incidence of aberrant endometrial alphavbeta(3) vitronectin expression in a high risk infertility population: could prolonged $\mathrm{GnRH}$ agonist therapy play a role? J Assist Reprod Genet 24, 553-556

7. Sanchez AM, Quattrone F, Pannese M et al (2017) The cannabinoid receptor $\mathrm{CB} 1$ contributes to the development of ectopic lesions in a mouse model of endometriosis. Hum Reprod 32, 175-184

8. Rakhila H, Girard K, Leboeuf M, Lemyre M and Akoum A (2014) Macrophage migration inhibitory factor is involved in ectopic endometrial tissue growth and peritonealendometrial tissue interaction in vivo: a plausible link to endometriosis development. PLoS One 9, e110434

9. Lee J, Banu SK, Burghardt RC, Starzinski-Powitz A and Arosh JA (2013) Selective inhibition of prostaglandin E2 receptors EP2 and EP4 inhibits adhesion of human endometriotic epithelial and stromal cells through suppression of integrin-mediated mechanisms. Biol Reprod 88,77

10. Khoufache K, Bondza PK, Harir N et al (2012) Soluble human IL-1 receptor type 2 inhibits ectopic endometrial tissue implantation and growth: identification of a novel potential target for endometriosis treatment. Am J Pathol $181,1197-1205$

11. Arici A (2002) Local cytokines in endometrial tissue: the role of interleukin-8 in the pathogenesis of endometriosis. Ann N Y Acad Sci 955, 101-109; discussion 118, 396-406

12. Garcia-Velasco JA and Arici A (1999) Interleukin-8 expression in endometrial stromal cells is regulated by integrin-dependent cell adhesion. Mol Hum Reprod 5, $1135-1140$

13. Omwandho CO, Konrad L, Halis G, Oehmke F and Tinneberg HR (2010) Role of TGF-betas in normal human endometrium and endometriosis. Hum Reprod 25, 101-109

14. Tamura M, Fukaya T, Enomoto A, Murakami T, Uehara S and Yajima A (1999) Transforming growth factor-beta isoforms and receptors in endometriotic cysts of the human ovary. Am J Reprod Immunol 42, 160-167

15. Pizzo A, Salmeri FM, Ardita FV, Sofo V, Tripepi M and Marsico S (2002) Behaviour of cytokine levels in serum and peritoneal fluid of women with endometriosis. Gynecol Obstet Invest 54, 82-87

16. D'Hooghe TM, Xiao L and Hill JA (2001) Cytokine profiles in autologous peritoneal fluid and peripheral blood of women with deep and superficial endometriosis. Arch 
Gynecol Obstet 265, 40-44

17. Dela Cruz C and Reis FM (2015) The role of TGFbeta superfamily members in the pathophysiology of endometriosis. Gynecol Endocrinol 31, 511-515

18. Chegini N (2008) TGF-beta system: the principal profibrotic mediator of peritoneal adhesion formation. Semin Reprod Med 26, 298-312

19. Sandoval P, Jimenez-Heffernan JA, Guerra-Azcona G et al (2016) Mesothelial-to-mesenchymal transition in the pathogenesis of post-surgical peritoneal adhesions. J Pathol 239, 48-59

20. Chin SL, Johnson SA, Quinn J et al (2003) A role for alphaV integrin subunit in TGF-beta-stimulated osteoclastogenesis. Biochem Biophys Res Commun 307, 1051-1058

21. Dou Q, Williams RS and Chegini N (1997) Inhibition of transforming growth factor-beta 1 alters the growth, anchor-dependent cell aggregation and integrin mRNA expression in human promonocytes: implications for endometriosis and peritoneal adhesion formation. Mol Hum Reprod 3, 383-391

22. Honda E, Yoshida K and Munakata H (2010) Transforming growth factor-beta upregulates the expression of integrin and related proteins in MRC-5 human myofibroblasts. Tohoku J Exp Med 220, 319-327

23. Moyano JV, Greciano PG, Buschmann MM, Koch M and Matlin KS (2010) Autocrine transforming growth factor\{beta\} 1 activation mediated by integrin $\{$ alpha\} $\vee\{$ beta $\} 3$ regulates transcriptional expression of laminin-332 in Madin-Darby canine kidney epithelial cells. Mol Biol Cell 21, 3654-3668

24. Young VJ, Brown JK, Saunders PT, Duncan WC and Horne AW (2014) The peritoneum is both a source and target of TGF-beta in women with endometriosis. PLoS One 9, e106773

25. Witz CA, Monotoya-Rodriguez IA and Schenken RS (1999) Whole explants of peritoneum and endometrium: a novel model of the early endometriosis lesion. Fertil Steril 71, 56-60

26. Witz CA, Allsup KT, Montoya-Rodriguez IA, Vaughn SL, Centonze VE and Schenken RS (2002) Culture of menstrual endometrium with peritoneal explants and mesothelial monolayers confirms attachment to intact mesothelial cells. Hum Reprod 17, 2832-2838

27. Witz CA, Thomas MR, Montoya-Rodriguez IA, Nair AS, Centonze VE and Schenken RS (2001) Short-term culture of peritoneum explants confirms attachment of endometrium to intact peritoneal mesothelium. Fertil Steril 75, 385-390

28. Lucidi RS, Witz CA, Chrisco M, Binkley PA, Shain SA and Schenken RS (2005) A novel in vitro model of the early endometriotic lesion demonstrates that attachment of endometrial cells to mesothelial cells is dependent on the source of endometrial cells. Fertil Steril 84, 16-21

29. Young VJ, Brown JK, Saunders PT and Horne AW (2013) The role of the peritoneum in the pathogenesis of endometriosis. Hum Reprod Update 19, 558-569

30. Campbell ID and Humphries MJ (2011) Integrin structure, activation, and interactions. Cold Spring Harb Perspect Biol 3

31. Merviel P, Challier JC, Carbillon L, Foidart JM and Uzan S
(2001) The role of integrins in human embryo implantation. Fetal Diagn Ther 16, 364-371

32. Umezawa M, Saito Y, Tanaka-Hattori N, Takeda K, Ihara T and Sugamata M (2012) Expression profile of extracellular matrix and adhesion molecules in the development of endometriosis in a mouse model. Reprod Sci 19, 1365-1372

33. Gupta D, Hull ML, Fraser I et al (2016) Endometrial biomarkers for the non-invasive diagnosis of endometriosis. Cochrane Database Syst Rev 4, CD012165

34. Klemmt PA, Carver JG, Koninckx P, McVeigh EJ and Mardon HJ (2007) Endometrial cells from women with endometriosis have increased adhesion and proliferative capacity in response to extracellular matrix components: towards a mechanistic model for endometriosis progression. Hum Reprod 22, 3139-3147

35. Koks CA, Groothuis PG, Dunselman GA, de Goeij AF and Evers JL (2000) Adhesion of menstrual endometrium to extracellular matrix: the possible role of integrin alpha(6)beta(1) and laminin interaction. Mol Hum Reprod 6, $170-177$

36. Puy LA, Pang C and Librach CL (2002) Immunohistochemical analysis of alphavbeta5 and alphavbeta6 integrins in the endometrium and endometriosis. Int J Gynecol Pathol 21, 167-177

37. Khoufache K, Bazin S, Girard K et al (2012) Macrophage migration inhibitory factor antagonist blocks the development of endometriosis in vivo. PLoS One 7, e37264

38. Chen J, Gu L, Ni J, Hu P, Hu K and Shi YL (2015) MiR-183 Regulates ITGB1P Expression and Promotes Invasion of Endometrial Stromal Cells. Biomed Res Int 2015, 340218

39. Rai V, Hopkisson J, Kennedy S, Bergqvist A, Barlow DH and Mardon HJ (1996) Integrins alpha 3 and alpha 6 are differentially expressed in endometrium and endometriosis. J Pathol 180, 181-187

40. Singh H and Aplin JD (2009) Adhesion molecules in endometrial epithelium: tissue integrity and embryo implantation. J Anat 215, 3-13

41. Witz CA (2003) Cell adhesion molecules and endometriosis. Semin Reprod Med 21, 173-182

42. Silginer M, Burghardt I, Gramatzki D et al (2016) The aryl hydrocarbon receptor links integrin signaling to the TGF-beta pathway. Oncogene 35, 3260-3271

43. Gutierrez J, Droppelmann CA, Contreras O, Takahashi C and Brandan E (2015) RECK-Mediated beta1-Integrin Regulation by TGF-beta1 Is Critical for Wound Contraction in Mice. PLoS One 10, e0135005

44. Hong SK, Park JR, Kwon OS, Kim KT, Bae GY and Cha HJ (2016) Induction of integrin beta3 by sustained ERK activity promotes the invasiveness of TGFbeta-induced mesenchymal tumor cells. Cancer Lett 376, 339-346

45. Yang X, Pursell B, Lu S, Chang TK and Mercurio AM (2009) Regulation of beta 4-integrin expression by epigenetic modifications in the mammary gland and during the epithelial-to-mesenchymal transition. J Cell Sci $122,2473-2480$

46. Scardigli R, Soddu S, Falcioni R, Crescenzi M, Cimino L and Sacchi A (1996) The beta 4 integrin subunit is expressed in mouse fibroblasts and modulated by transforming growth factor-beta 1. Exp Cell Res 227, 223-229 